\title{
Research on the Transformation and Development of Japanese Majors under the Concept of General Education
}

\author{
Ning Ding, Ying Huang, Pei Wang \\ College of Foreign Language Education \& International Business, Baoding University, Baoding, China \\ Email: tyokun@126.com
}

How to cite this paper: Ding, N., Huang, Y., \& Wang, P. (2020). Research on the Transformation and Development of Japanese Majors under the Concept of General Education. Creative Education, 11, 1741-1750. https://doi.org/10.4236/ce.2020.119127

Received: September 4, 2020

Accepted: September 20, 2020

Published: September 23, 2020

Copyright $\odot 2020$ by author(s) and Scientific Research Publishing Inc. This work is licensed under the Creative Commons Attribution International License (CC BY 4.0).

http://creativecommons.org/licenses/by/4.0/

\begin{abstract}
General education is an inevitable choice for cultivating all-round development talents. Integrating general education concepts into Japanese professional teaching can effectively improve the effectiveness and timeliness of Japanese professional teaching. General education focuses on students' grasp of multi-disciplinary knowledge, so as to form a sound personality, innovative consciousness and scientific habits, and then truly apply what they have learned. At present, the teaching philosophy of Japanese majors is lagging behind, the teaching model is outdated, and the teaching method is single. The integration of general education concepts can effectively solve the difficulties encountered in Japanese teaching. In view of this, in the transformation and development of the Japanese major, it is necessary to accelerate the reform of the teaching concept of the Japanese major, accelerate the reconstruction of the teaching system of the Japanese major, strengthen and optimize the evaluation system of the Japanese major, and finally enhance the interest, efficiency and application of the Japanese major teaching, and finally cultivate to produce Japanese professionals with solid professionalism, sound personality and comprehensive development.
\end{abstract}

\section{Keywords}

General Education, Japanese Major, Transformational Development, Education Model, Talent Cultivation

\section{Introduction}

With the continuous development of the economy and society and the continuous improvement of education level, cultivating comprehensive talents with 
excellent professional quality and sound personality has become an important goal in the education field. This has made the concept of general education gradually paid attention to by the education community and promoted various disciplines. The integration of teaching and general education concepts has developed into the consensus of academia and practice, and Japanese majors are no exception (Ding, 2019). As we all know, language is the carrier and important form of expression of culture. The Japanese major is a foreign language and literature major. Its training goal is to require students to have a certain level of Japanese use ability, Japanese text reading and writing ability, and Japanese cultural analysis ability and the comprehensive ability of subject research and innovation (Li, 2020). Therefore, the study of Japanese majors requires students to have a broad understanding of Japan's economic development, social culture, and ideological concepts, so that they can quickly master Japanese language habits and language styles, and then achieve rapid Japanese application skills improve.

However, the current Japanese majors in our country generally have problems such as insufficient interest, insufficient effectiveness, low timeliness, and poor continuity, which severely restrict the benign development trend of the Japanese language education major and are not conducive to the cultivation of Chinese Japanese professional talents and development (Wang \& Sun, 2019). Therefore, my country must explore the reform of the Japanese professional education and teaching system and promote the transformation and development of the Japanese professional. The application of general education concepts can effectively resolve this problem. Based on this, the author based on the analysis of the connotation of the general education concept, combined with the current problems and difficulties faced by the Japanese language education and teaching in our country, focuses on exploring the important role of the general education concept in promoting the transformation and development of the Japanese major, and then analyzes the general education concept. The path of the transformation and development of the Japanese major will ultimately promote the efficient, innovative and sustainable development of the teaching of the Japanese major in our country, and cultivate comprehensive and high-quality talents with strong professional qualities and sound personalities. It has great theoretical value and strong practical significance (Zhao, 2020).

\section{Overview of the Connotation of General Education Concepts}

\subsection{The Development History of General Education Concepts}

The term "general education" is a typical representative of the combination of Chinese and foreign cultures. It not only embodies the meaning of foreign "General Education", but also draws on the interpretation of "tong" and "knowledge" in traditional Chinese culture in translation. General education originated in the 19th century, and the motivation was that the division of specialized dis- 
ciplines was too detailed, which resulted in the fragmentation of knowledge, which in turn restricted the development and application of various disciplines (Zou, 2020). At the same time, with the continuous development of human society, society's requirements and definitions for talents not only include high standards and high requirements for professionalism, but also include independent thinking, innovative exploration, and With high expectations in terms of character and personality, general education has been rapidly developed and promoted.

Due to the relatively high level of economic development in Europe and the United States, general education has developed rapidly in Europe and the United States in modern history and has gradually evolved into a compulsory subject in higher education institutions. In modern times, the development of general education in my country is relatively late, but at a faster speed ( $\mathrm{Wu} \&$ Zhang, 2020). Moreover, general education has a long history of development in our country. Many classic ancient teaching materials have educational concepts related to general education. For example, in "The Doctrine of the Mean", it is clearly stated that learning should be "learned, interrogated, deliberate, discerning, and practiced" (Shi \& Fan, 2020). At present, colleges and universities at all levels in our country are accelerating the integration of general education concepts and professional education. Although there are certain difficulties, the development trend is very clear.

\subsection{Basic Characteristics of General Education Concepts}

In essence, there is no obvious boundary between general education and professional education. The difference between the two is mainly reflected in the choice of education mode and the difference in teaching values. From this perspective, we can analyze the basic characteristics of general education concepts and inquiry, which has a very important value and role in studying how general education concepts promote the transformation and development of Japanese majors (Zhou, 2020).

First of all, general education has obvious people-oriented education characteristics, mainly based on the needs of students as the first principle, and give full play to the creativity and imagination of students; second, general education highlights the status of students as the main body of teaching, general education The model encourages students to acquire professional knowledge through diversified student models and methods, which in turn enables a higher degree of mastery of professional knowledge and a more skillful application; furthermore, general education is a kind of humanistic education that emphasizes and promotes The guidance of values, outlook on life and world outlook effectively breaks through the utilitarian nature of professional subject teaching, enabling students to have independent thinking ability and independent personality. It can be seen that the development of general education can effectively assist the teaching and research of professional subjects (Gao, 2016). 


\section{Analysis of the Development Dilemma of the Japanese Major}

With the increasingly frequent economic, cultural, technological and political exchanges between my country and Japan, the society's demand for Japanese professionals is rapidly increasing, especially in Northeast China, where the demand for Japanese professionals is even stronger. The strong demand for Japanese talents has promoted the rapid development of Japanese majors, and also led to the expansion of the training team of Japanese majors in universities (Jin \& Fan, 2020). However, in the context of the continuous expansion of enrollment scale, the development dilemma of the Japanese major is also constantly emerging. The specific analysis is as follows.

\subsection{The Educational Concept of the Japanese Major Is Lagging Behind, and the Application of Japanese Teaching Is Not High}

The lagging of the educational philosophy of the Japanese major is the primary dilemma for the development of the Japanese major, which is mainly reflected in the low applicability of Japanese teaching. The Japanese major is a language major, practical application is the most basic cultivation goal, and it is also the key for students to learn Japanese better. However, the current teaching of Japanese majors in colleges and universities lacks consideration of students' practical application of Japanese, and mainly focuses on the examination of knowledge points. As a result, many schools and teachers only pay attention to the completion of teaching tasks and ignore the training of students' Japanese application ability. Students will "take the exam", but they cannot really apply Japanese flexibly in real life. At present, many college students majoring in Japanese still have obvious obstacles to the daily operation of Japanese. This is not only a restriction of the language learning environment, but a lag in the teaching concept of the entire Japanese major.

\subsection{The Educational Model of the Japanese Major Is Outdated, and the Effectiveness of Japanese Teaching Is Not Good}

The outdated education model of the Japanese major is the core drawback of the development of the Japanese major, which mainly reflects the poor effectiveness of Japanese teaching. For a long time, the Japanese language teaching in our country has adopted a more traditional method. The teaching method is relatively conservative, the teaching content is relatively lagging, and the teaching methods are very backward. This not only makes the teaching of Japanese majors boring and boring, makes students lack interest, but also makes Japanese majors. The teaching atmosphere has become worse, which is not conducive to the sustainable development and virtuous circle of Japanese teaching. Taking the problem of teaching materials as an example, the Japanese teaching materials of many colleges and universities are seriously out of the real life of students. Therefore, students are not very motivated during the teaching process, which 
ultimately inhibits the improvement of teaching effects. Judging from the actual situation, the low level of Japanese first-level pass rate in many colleges and universities is generally low, which fully shows the lack of effectiveness of current Japanese teaching.

\subsection{The Teaching Method of the Japanese Major Is Single, and the Japanese Teaching Is Not Interesting}

The single education method of the Japanese major is an important dilemma for the development of the Japanese major, which is mainly reflected in the lack of interest in Japanese teaching. Classroom teaching is a commonly adopted method in traditional Japanese professional teaching, which makes Japanese teaching that lacks a language learning environment even more difficult. Judging from the teaching situation of Japanese majors in various universities, traditional classroom teaching is still the main method. Online and offline teaching methods are rarely used, and there is a lack of open communication and discussion. The atmosphere of Japanese majors is relatively poor. The difficulty of superimposing the learning of Japanese itself is great, which ultimately makes Japanese teaching less interesting, and the staff's attention is not enough. Finally, it is difficult for the teaching of Japanese majors to cycle forward.

\section{The Important Role of General Education Concepts in Promoting the Transformation and Development of Japanese Majors}

To clarify the important role of general education concepts in promoting the transformation and development of the Japanese major, and to efficiently sort out the motivations of the general education concepts to promote the transformation and development of the Japanese major, which is conducive to more targeted exploration to promote the transformation and development of the Japanese major Countermeasures and paths. This thesis mainly analyzes and elaborates from the three dimensions of improving the teaching system of Japanese majors, enriching the teaching models of Japanese majors, and optimizing the teaching evaluation of Japanese majors.

\subsection{The Integration of General Education Concepts Can Improve the Teaching System of Japanese Majors}

The integration of general education concepts can improve the teaching system of Japanese majors and effectively improve the comprehensive level of Japanese majors.

First of all, general education emphasizes comprehensive education and pragmatic education. The integration of general education concepts into the teaching of Japanese in colleges and universities can promote the teaching of Japanese in colleges and universities from reality, connect Japanese teaching with market demand, and establish a new education and teaching. Concept, and then optimize the quality of teaching content. 
Secondly, general education pays attention to the teaching and guidance of culture, technology, society, politics, etc., which will more effectively enhance the interest of Japanese professional teaching, thereby increasing students' interest in learning, and effectively improving the integration of Japanese professional teaching Level.

Furthermore, with the introduction of general education concepts, the teaching atmosphere of Japanese majors will be greatly improved, which is conducive to creating a better language learning atmosphere and environment for students, thereby promoting the rapid improvement of Japanese majors.

\subsection{The Practice of General Education Concepts Can Enrich the Teaching Mode of Japanese Majors}

The practice of general education concepts can enrich the teaching mode of Japanese majors and effectively improve the overall effectiveness of Japanese major teaching, which benefits from the scientific education concepts of general education.

First, general education is people-oriented, pays attention to the satisfaction of students' needs, and highlights the subject status of students in teaching activities. Therefore, through the practice of general education concepts, students' status in Japanese majors can be effectively improved, thereby inspiring students Learning interest.

Second, general education emphasizes application, which makes the teaching of Japanese in colleges and universities more pragmatic. Students' learning goals are clearer, learning motivation is more abundant, learning strategies are more diverse, and learning methods are more diverse. These will improve students' understanding of Japanese. Language application ability and analytical ability, and then enrich the teaching mode of Japanese majors, and ultimately enhance the effectiveness of teaching.

Third, general education pays attention to the grasp of the times, which is to associate professional knowledge with the culture, system, and technology of the time in which students live. This will greatly eliminate the current lagging Japanese language professional textbooks and content in colleges and universities. Enhance the timeliness of Japanese teaching, and truly realize the advancement of Japanese teaching and social development.

\subsection{The Application of General Education Concepts Can Optimize the Teaching Evaluation of Japanese Majors}

The application of general education concepts can optimize the teaching evaluation of Japanese majors, and help boost the subject confidence of Japanese majors. This is conducive to making Japanese teaching enter a positive cycle, and then realize the efficient, stable and sustainable development of Japanese teaching in my country. Educational goals.

On the one hand, the integration of general education concepts will optimize 
the teaching performance evaluation of Japanese teachers, because general education focuses on the cultivation of practical ability, the excavation of innovation ability, and the cultivation of independent thinking ability. The establishment of these cultivation goals makes The difficulty of teaching Japanese majors has increased, so college Japanese teachers are forced to be more pragmatic and more active in teaching.

On the other hand, the integration of general education concepts will optimize the evaluation of the learning effect of Japanese majors. Under the concept of general education, colleges and universities have more scientific evaluations of students' Japanese learning conditions, so that the pressure and motivation of students' learning are improved, and the subjective initiative of students will be fully displayed, ultimately achieving a win-win situation for teachers and students.

\section{Strategic Research on the Transformation and Development of Japanese Majors under the Concept of General Education}

Based on the previous research, this thesis will analyze the path of the transformation and development of the Japanese major under the general education concept from the three dimensions of the Japanese major education concept, the Japanese major teaching system, and the Japanese major evaluation system. The specific analysis is as follows.

\subsection{Innovate the Educational Concept of Japanese Majors and Adhere to the Application-Oriented Teaching Principles of Japanese Majors}

Innovating the concept of Japanese major education is the primary strategy for the transformation and development of the Japanese major under the concept of general education. The core measure is to adhere to the application-oriented teaching principle of Japanese major.

First, the teaching of high-tech Japanese majors should adhere to the starting point of cultivating students' practical and applied Japanese ability and pay attention to the improvement of students' Japanese application ability.

Second, we must adhere to the teaching philosophy of seeking truth from facts. Starting from the actual situation, we must match the teaching content of Japanese majors with market needs, and ensure that students' professional knowledge learning is in line with market needs. This will not only improve the effectiveness of teaching, it will also be beneficial. Improve the enthusiasm of students.

Third, it is necessary to set up a reasonable teaching form for Japanese majors, scientifically use Japanese majors teaching tools, comprehensively search for and use high-quality Japanese majors teaching resources, so as to truly improve the quality of Japanese teaching in colleges and universities, and enhance students' ability to use Japanese. 


\subsection{Reconstruct the Teaching System of Japanese Majors and Highlight the Student-Oriented Teaching Model of Japanese Majors}

Reconstructing the teaching system of Japanese majors is the core strategy for the transformation and development of Japanese majors under the concept of general education. The core measure is to highlight the student-oriented teaching model of Japanese majors.

First of all, we must be people-oriented, respect students' dominant position in teaching activities, create more opportunities for students to use Japanese, and exercise and judge students' mastery of Japanese in classroom exercises, and then give students targeted learning Suggestions, and constantly improve their own teaching plans and teaching content.

Secondly, the reasonable setting of Japanese teaching content should not only consider the acceptability of students, but also take into account the interestingness, continuity and depth of thought of the content. While cultivating students' Japanese skills, we should introduce as much Japanese human knowledge as possible. And set up corresponding questions for discussion to improve the depth of students' thinking, so that students can understand the correct learning methods and learning strategies while mastering Japanese ability.

Finally, on the basis of introducing, mastering, and understanding Japanese culture, teach the essentials of Japanese knowledge and guide students to start Japanese learning, which will be smoother and the efficiency of Japanese learning will also be improved.

\subsection{Optimize the Evaluation System of Japanese Majors to Form a Capability-Oriented Teaching Evaluation of Japanese Majors}

Optimizing the evaluation system of Japanese majors is an important supplementary strategy for the transformation and development of Japanese majors under the concept of general education. The core measure is to form an ability-oriented teaching evaluation of Japanese majors.

At the teacher level, on the one hand, it is necessary to re-examine the educational level and research level of Japanese professional teachers, pay attention to whether teachers understand Japanese culture, economy, science, politics, etc., and highlight the consideration of non-professional knowledge points, and promote Before the students' comprehensive ability is cultivated, expand the knowledge of Japanese teachers; on the other hand, it is necessary to optimize the evaluation of teaching achievements of Japanese teachers, not only the evaluation of student test scores and the evaluation of teachers' papers or scientific research results, but also Pass rate of students' Japanese-related certificates, students' Japanese communication skills, etc.

At the student level, it is mainly necessary to highlight the inspection of students' practical Japanese ability, and to introduce corresponding measures to guide students to actively use Japanese and improve their Japanese application 
ability. At the same time, we also need to focus on the cultivation of students' independent thinking ability and innovative exploration ability.

\section{Research Conclusion}

All in all, the concept of general education conforms to the basic requirements and key standards of Japanese professional teaching. Promoting the integrated development of the general education concept and Japanese professional teaching is an inevitable measure and beneficial exploration for the efficient, rapid and sustainable development of the Japanese major in colleges and universities. General education not only focuses on the assessment of students' overall abilities, but also focuses on the assessment of students' character. In retrospect, there are problems in the teaching of Japanese majors in colleges and universities in my country, such as lagging teaching concepts, outdated teaching models and single teaching methods. The integration of general education concepts can effectively solve the difficulties encountered in Japanese teaching. Under this circumstance, our country must accelerate the transformation and development of the Japanese major. Specifically, under the concept of general education, it must accelerate the reform of the teaching concept of the Japanese major, accelerate the reconstruction of the Japanese major teaching system, strengthen the optimization of the Japanese major evaluation system, and finally enhance the interest, efficiency and application of Japanese professional teaching, and finally cultivate Japanese professionals with solid professionalism, sound personality and comprehensive development.

\section{Fund Project}

This paper belongs to the research results of the 2018 Hebei Province Social Science Development Research Project "Research on Japanese Professional Development under the Concept of General Education" (project number: 201804040103).

\section{Conflicts of Interest}

The authors declare no conflicts of interest regarding the publication of this paper.

\section{References}

Ding, N. (2019). Research on the Development of Japanese Major under the Concept of General Education. Think Tank Times, No. 6, $192+195$.

Gao, Z. H. (2016). On How to Build a Micro-Course Resource for the Japanese Major in Higher Vocational Education Based on the Network Platform-Take the Course "Integrated Japanese" as an Example. Times Education, No. 22, 97-98.

Jin, Y. H., \& Fan, M. (2020). A Follow-Up Survey on the Development of Cross-Cultural Communicative Competence: Taking Japanese Majors Abroad as an Example. Japanese Language Learning and Research, No. 1, 71-79.

Li, R. (2020). The Construction and Exploration of the Practical Teaching Mode of Japa- 
nese Language Majors in Colleges and Universities in Beijing. Education Teaching Forum, No. 9, 157-159.

Shi, F. Q., \& Fan, T. T. (2020). The Influence of Japanese Drama on the Professional Outlook and Interpersonal Communication of Japanese Majors. Shanxi Youth, No. 6, 42-43.

Wang, Y., \& Sun, C. (2019). The Enlightenment of Japan's “Easy Education” Reform on the Employment Problems of Japanese Majors. Time-Honored Brand Marketing, No. $11,55-56$.

Wu, L., \& Zhang, P. (2020). The Influence of the Learning Attitude of Japanese Majors on Learning Investment and the Education Reform Countermeasures in the Era of Big Data. Heilongjiang Higher Education Research, 38, 111-115.

Zhao, H. (2020). An Analysis of the Importance of Introducing Japanese Culture and Art into the Teaching of Japanese in Colleges and Universities. Popular Science (Science Education), No. 4, 120-121.

Zhou, T. (2020). Talking about Japanese Professional Micro-Classes under the Background of Building a Curriculum Resource Bank-Taking Liaoyang Vocational and Technical College as an Example. Journal of Liaoning Teachers College (Social Science Edition), No. 1, 71-72.

Zou, Y. L. (2020). Analysis of Japanese Learning and Teaching Methods in Independent Colleges and Universities-Taking the Japanese Major of Shanxi University Business School as an Example. Fujian Tea, 42, 254. 